\title{
The August 17 Kocaeli and the November 12 Duzce earthquakes in Turkey
}

\author{
Muhammed Sahin and Ergin Tari \\ Istanbul Technical University, Faculty of Civil Engineering, Department of Geodesy and Photogrammetry, 80620 Maslak, Istanbul, Turkey
}

(Received December 25, 1999; Revised June 7, 2000; Accepted June 7, 2000)

\begin{abstract}
Two devastating earthquakes occurred in Turkey, one on August 17 and the other on November 12, 1999. The magnitudes were 7.4 and 7.2 respectively. The epicenter of the first earthquake was located near Golcuk, a town near Kocaeli province, $110 \mathrm{~km}$ from Istanbul. The epicenter of the second earthquake was in Duzce, $150 \mathrm{~km}$ from Istanbul. The first earthquake occurred after midnight and killed more than 15000 people. This number is obtained from an official report, while the actual deaths are expected to be more than 20,000. The earthquake was a nightmare for the whole country, and affected almost 10 cities including Istanbul. The second earthquake occurred on November 12 in the early evening, and killed about 1000 people. The affected area from the two earthquakes has a population of about 20 million, which is one third of the whole population of the country, and almost half of the Turkish economical infrastructures is located in this region. This paper gives an overview of the two devastating earthquakes, including geological background of the region, economical impacts and degrees of damages on different aspects.
\end{abstract}

\section{Introduction}

The Anatolian Block is compressed by African and Arabian Plates from the south and Eurasian Plate from the north. This compression is responsible for complex deformation of the North Anatolian Fault Zone (NAFZ) that causes major earthquakes along the fault (Fig. 1). Arabian plate is moving in a north-northwest direction relative to Eurasia. The plate tectonic models and the last ten years of GPS observations around the region suggest that the African plate is also moving in a northward direction relative to Eurasia. The reasonable agreement between present day GPS observations and the estimated age of faulting suggests that the AnatoliaEurasia motion has continued for the last 4-5 m.y (Reilinger et al., 2000).

The North Anatolian Fault (NAF) with a length of $1500 \mathrm{~km}$ is one of the most active and largest strike-slip faults in the world, which causes destructive earthquakes by slipping at an average rate of $20-25 \mathrm{~mm} / \mathrm{yr}$ (Fig. 2). NAF is the most active component in the tectonic evolution of Anatolia. Within this century more than 25 earthquakes have occurred along the fault ruptured over $900 \mathrm{~km}$ of its length (Barka and Nalbant, 1998). The NAF starts from the Karliova in the east and extends to the Gulf of Saroz in the west (Figs. 2 and 3). There are large pull-apart and fault band basins along the NAF, which are preferred for residential areas. Unfortunately, most of the Turkish industry is also located in these basins (Tuysuz and Genc, 1999).

The extension of the NAF in the Marmara Sea is not well known, although the land part is well mapped. The NAF is divided into two segments in the west of Bolu, $200 \mathrm{~km}$ from Istanbul and enters into the Marmara Sea via the Izmit (center of the Kocaeli province) and Gemlik Bays (Fig. 2) (Okay et

Copy right $(\mathrm{C})$ The Society of Geomagnetism and Earth, Planetary and Space Sciences (SGEPSS); The Seismological Society of Japan; The Volcanological Society of Japan; The Geodetic Society of Japan; The Japanese Society for Planetary Sciences. al., 1999). The northern most active strand passes beneath the Sea of Marmara, while the southern strand remains on land south of the Sea (Ferrari et al., 2000). According to the latest data, it is stated that the NAF also splits into a number of sub-fault zones, fault set and isolated faults in and circum Sea of Marmara (Kocyigit, 2000).

\section{Significant Earthquakes in the Marmara Re- gion}

The Marmara section of the North Anatolian Fault was broken two times, one in 1509 and the other in 1766 (Le Pichon et $a l ., 1999)$. The first one was the most destructive earthquake of the last five centuries in the Eastern Mediterranean. The epicenter was in the Marmara Sea and destroyed the region between Bolu-Istanbul-Gelibolu, about $200 \mathrm{~km}$ long. This earthquake was felt from Crimea to Egypt (Sengor, 1999). The earthquake killed 5000 people and ruptured the whole fault system, from the Gulf of Saroz to Gulf of Izmit. Sand boils were also reported as well as sea floods. (Le Pichon et al., 1999). Table 1 and Fig. 3 show the historical earthquakes that have occurred in the region.

\section{The August 17, 1999 Kocaeli Earthquake}

The August 17, 1999 Kocaeli earthquake occurred at 03:02 a.m. (Local Time), which ruptured about $140 \mathrm{~km}$ of the surface (Fig. 4). The epicenter was Golcuk at the eastern end of Marmara Sea, Longitude 29.91E and Latitude 40.70N. The Earthquake Research Department (ERD) of Turkey declared the magnitude to be Mw: 7.4, and the depth was about $10 \mathrm{~km}$. The earthquake affected residential parts and city centers of Golcuk, Yalova, Adapazari (center of the Sakarya province), Izmit, Avcilar (Istanbul), Duzce, Akyazi, Golyaka, Sapanca and Korfez (Izmit). Many buildings were completely destroyed in the residential parts (Fig. 5). The Istanbul-Ankara Expressway and the railway line were damaged, that stopped the traffic for two days (Figs. 6 and 7). The TUPRAS 


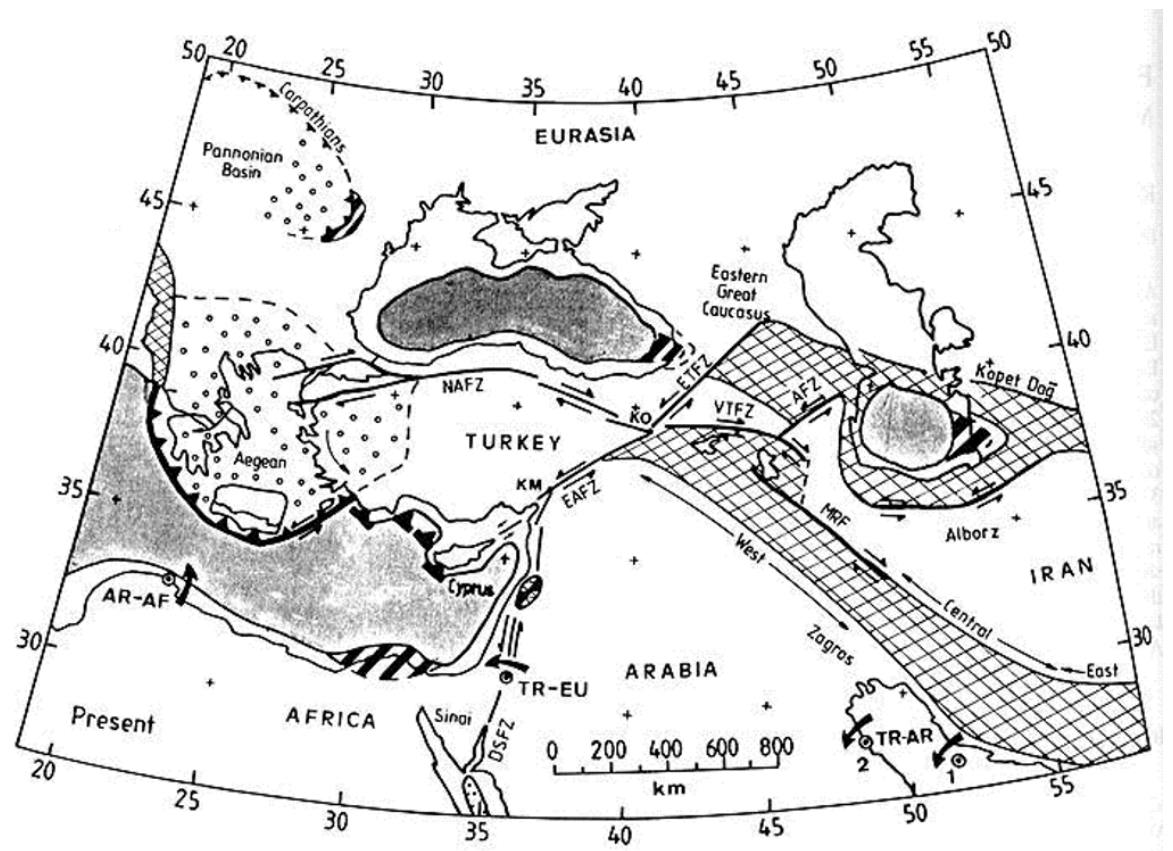

Fig. 1. Tectonic features of Turkey.

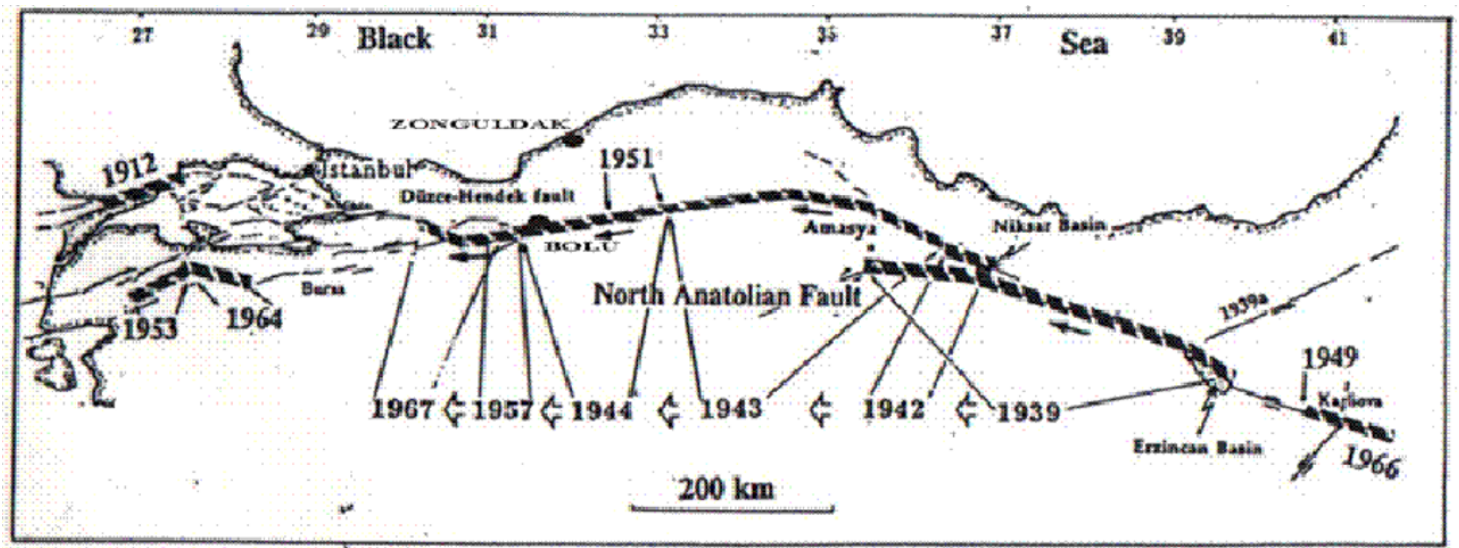

Fig. 2. Earthquakes along the North Anatolian Fault in this century (USGS web site).

petroleum refinery was on fire for 6 days. The communication stopped for two days.

There were many special rescue teams from many parts of the world who rescued and evacuated thousands of people successfully. In addition, mobile hospitals were setup by several countries to treat wounded people. The most important rescue operation was that a child was rescued after nine days. The ERD has collected all the records from TURKNET that operates 19 stations and transferred the records to the central computer in Ankara via data-lines. After the main shock, more than 2400 aftershocks were recorded in different magnitudes.

According to the latest information from the Crisis Center in Ankara, the death toll of the earthquake is 15,851 , and the reported injuries are 43,953. The distribution of the reported casualties is as follows: Golcuk (5025), Kocaeli
(4093), Sakarya (2629), Yalova (2502), Istanbul (981), Bolu (264), Bursa (268), Eskisehir (86) and Zonguldak (3).

\section{Economic Impact of the Kocaeli Earthquake}

According to the information from the General Directorate of Disaster Affairs of the Ministry of Public Works and Settlement, the damage evaluation reports confirm the estimated figures. There may be some changes on the final damage figures due to the objections by the owners to change the degree of damage.

As seen in Table 2, the total number of house unit collapsed and heavily damaged is 66,403 , and the owner or occupant families of these houses are now homeless. Most of them live in prefabricated houses and tents, but some moved from the region to other places. After the damage evaluation, 66,863 house units are classified as moderately damaged. So it is 
Table 1. Damaging earthquakes in the eastern Marmara region that occurred during the last two millennia.

\begin{tabular}{|c|c|c|}
\hline Date & City name & Comments \\
\hline 29 Nov. 24 & Izmit & Damaged \\
\hline 69 & Izmit & Destroyed \\
\hline 121 & Izmit & Comletely destroyed \\
\hline 128 & Izmit & Destroyed \\
\hline 269 & Izmit-Duzce & Damaged the region from Izmit to Duzce \\
\hline 362 Dec. 2 & Izmit & Totally destroyed \\
\hline 446 Jan. 26 & Izmit Gulf & Damaged \\
\hline 478 Sep. 25 & Karamursel-Izmit & Totally destroyed with great loss of life \\
\hline 554 Aug. 16 & Izmit & Destroyed \\
\hline 740 Oct. 26 & Izmit-Karamursel-Iznik & Damaged \\
\hline 989 Oct. 25 & Izmit & Heavy damaged in eastern Esa of Marmara \\
\hline 1064 Sep. 23 & Istanbul-Izmit & Damaged the region from Istanbul to Izmit \\
\hline 1509 Sep. 10 & Marmara Sea & The most destructive earthquake \\
\hline 1567 Oct. 1 & Izmit & Damaged the region from Istanbul to Izmit centered at Sapanca \\
\hline 1672 May 25 & Izmit & Damaged \\
\hline 1719 May 25 & Yalova, Karamursel, Izmit, Sapanca & Destroyed the whole region occurred in the east part of Sea of Marmara \\
\hline 1754 Sep. 2 & Izmit Gulf & Villages were totally destroyed and about 2000 people were killed \\
\hline 1766 & Marmara & Very destructive earthquake \\
\hline 1878 Apr. 19 & Izmit & Damaged \\
\hline 1894 Jul. 10 & Izmit Gulf & $\begin{array}{l}\text { Extensively damaged the region between Istanbul and Adapazari, } \\
\text { with great loss of life. Most villages in Heybeliada, } \\
\text { Yalova and Sapanca were totally destroyed }\end{array}$ \\
\hline 1943 Jun. 20 & Hendek & $\begin{array}{l}\text { Ms }=6.5, \text { Heavy damage in the region between Adapazari, Hendek, } \\
\text { Akyazi and Arifiye }\end{array}$ \\
\hline 1957 May 26 & Abant & $\mathrm{Ms}=7.0,40 \mathrm{~km}$ fault rupture \\
\hline 1963 Sep. 18 & Yalova & $\mathrm{Ms}=6.3$, extensive damage in the region between Çinarcik and Yalova \\
\hline 1967 Jul. 22 & Mudurnu & $\mathrm{Ms}=7.1,80 \mathrm{~km}$ fault rupture \\
\hline 1999 Aug. 17 & Izmit & $\begin{array}{l}\text { Ms }=7.4 \text {, extensive damaged in the whole Marmara region with } \\
\text { more than } 15000 \text { people killed }\end{array}$ \\
\hline 1999 Nov. 12 & Duzce & $\mathrm{Ms}=7.2$, heavy damage with more than 1000 people killed \\
\hline
\end{tabular}

dangerous to live in these houses without a proper repairing and strengthening operation. Total number of slightly damaged housing units are 79,630. It is possible to live in but an immediate repair is necessary. The efforts in removing the debris of collapsed or heavily damaged buildings are in progress.

The Ministry of Public Works and Settlement continues to construct prefabricated houses for temporary housing. Total number of prefabricated houses has reached up to 25,000 . The total number of distributed tents to the people exceeded 112,250 . There are 121 tent-villages in the disaster area.

There are several organizations who have some estimates about the economic impact of the earthquake. The followings are only the summary and rough estimates (Ural, 1999).

\begin{tabular}{ll} 
TUBITAK (Scientific and Technical & \\
\multicolumn{1}{c}{ Research Council of Turkey) } & 20 Billion USD \\
Ministry of State & 10 Billion USD \\
National Housing Authority & 20 Billion USD \\
United Nations & 25 Billion USD \\
World Bank & 6.5 Billion USD
\end{tabular}

\section{November 12, 1999 Duzce Earthquake}

The November 12 Duzce earthquake is the second largest earthquake which ruptured $45 \mathrm{~km}$ of surface. Horizontal and 


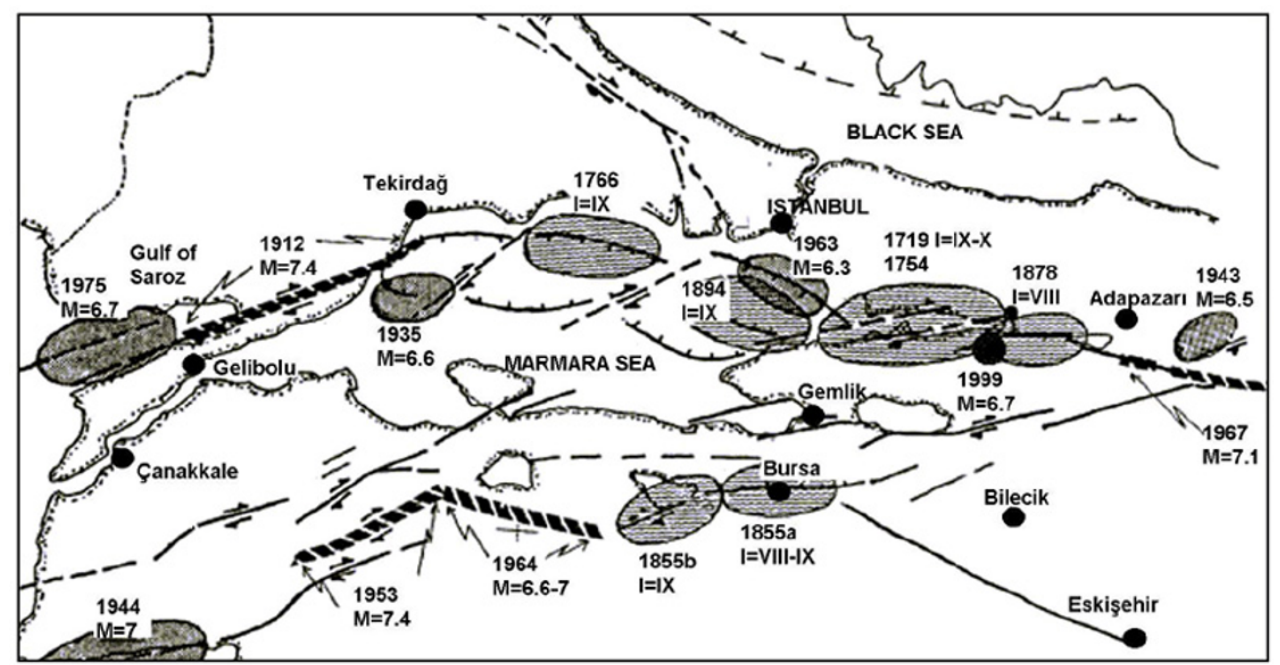

Fig. 3. Major historical earthquakes in 300 years (Barka, 1997).

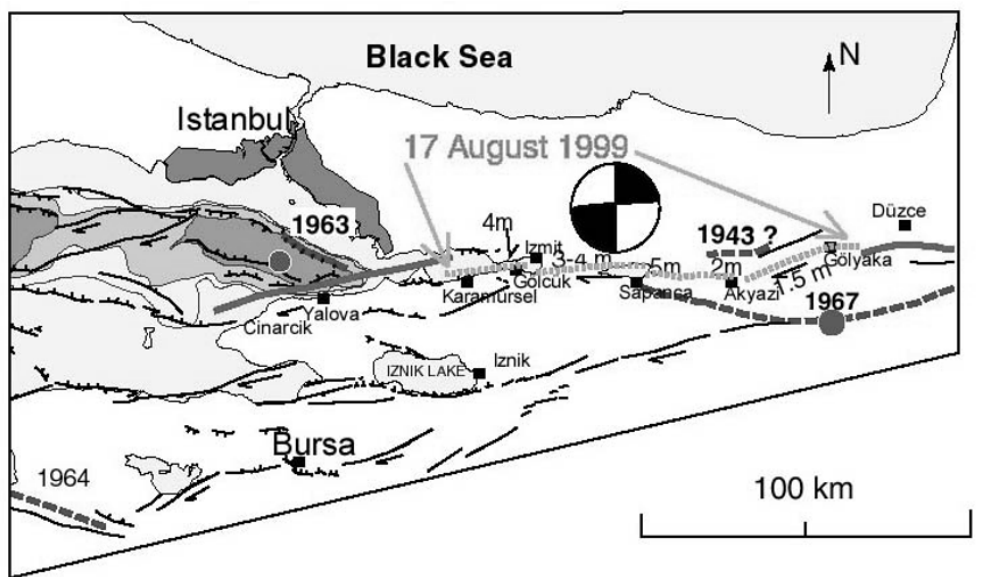

Fig. 4. August 17, 1999 Kocaeli earthquake (Barka, 1999a).

Table 2. Summary of distribution for the units of damaged houses.

\begin{tabular}{lccc}
\hline & $\begin{array}{c}\text { Collapsed or heavily } \\
\text { damaged }\end{array}$ & $\begin{array}{c}\text { Moderately } \\
\text { damaged }\end{array}$ & $\begin{array}{c}\text { Slightly } \\
\text { damaged }\end{array}$ \\
\hline Sakarya & 19,043 & 12,200 & 18,720 \\
Golcuk & 12,310 & 7,789 & 9,299 \\
Kocaeli & 19,315 & 21,287 & 22,452 \\
Istanbul & 3,073 & 13,339 & 12,455 \\
Yalova & 9,462 & 7,917 & 12,685 \\
Bolu & 3,095 & 4,180 & 3,303 \\
Bursa & 29 & 104 & 401 \\
Eskisehir & 76 & 47 & 315 \\
\hline Total & $66,403(31.2 \%)$ & $66,863(31.4 \%)$ & $79,630(37.4 \%)$ \\
\hline
\end{tabular}

vertical displacements, with $3.0 \mathrm{~m}$ and $5.0 \mathrm{~m}$ respectively, have occurred along the rupture (Taymaz, 1999). The west end of the rupture line located close to the point of the east end of the rupture line of the August 17 earthquake (Barka, 1999b). The measured magnitude is 7.2, which devastated much of the two towns of Kaynasli and Duzce, and killed 


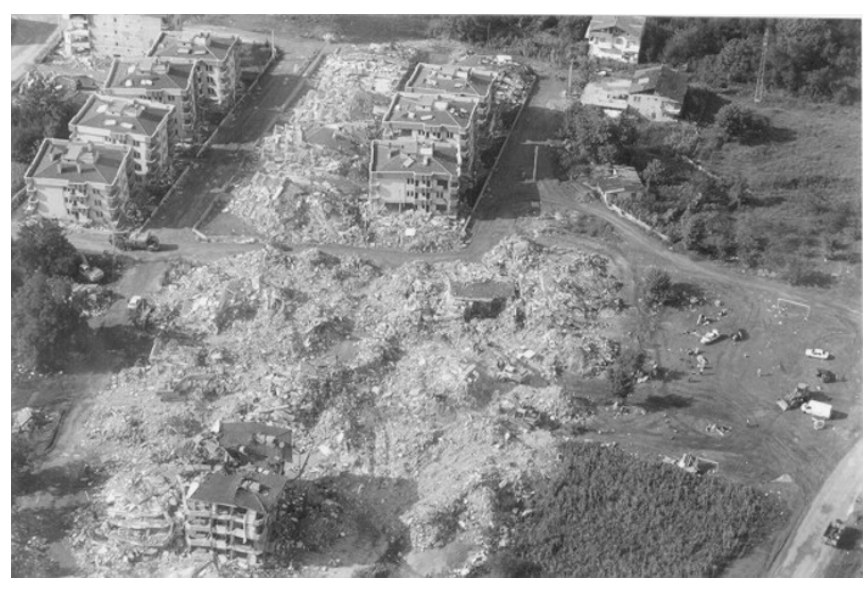

Fig. 5. Collapsed building in residential areas (photo by A. Barka).

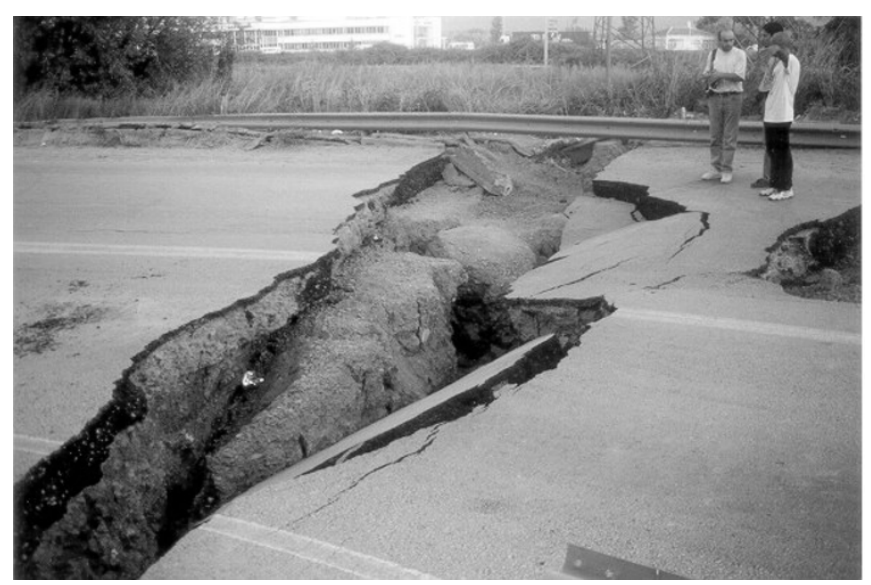

Fig. 6. Istanbul-Ankara Highway (photo by A. Barka).

about 1000 people. Comparing to the August 17, 1999 earthquake, there were less people killed. The reason for this is that the density of the population is much less than the first earthquake area, and that the local time was 18:58 when the people were about to arrive home from the work.

\section{Conclusion}

The continuing discussion on the Marmara Region is that there will certainly be an earthquake between 6.5 and 7.7. There are basically two ideas about the future earthquake that will most probably occur in the Marmara Sea which will directly affect the city of Istanbul. The first idea is that the whole Marmara segment will be broken at once and will produce an earthquake of 7.7. The second idea is that the Marmara segment will be broken in several steps which will produce an earthquake of less than 7.0. Either earthquake will destroy the region, mainly Istanbul. Therefore, the Turkish Authorities are about to install most recent seismological instruments and improve the continuous GPS network to control the possible future earthquake. In addition, an earthquake alarm system will be installed in Istanbul in

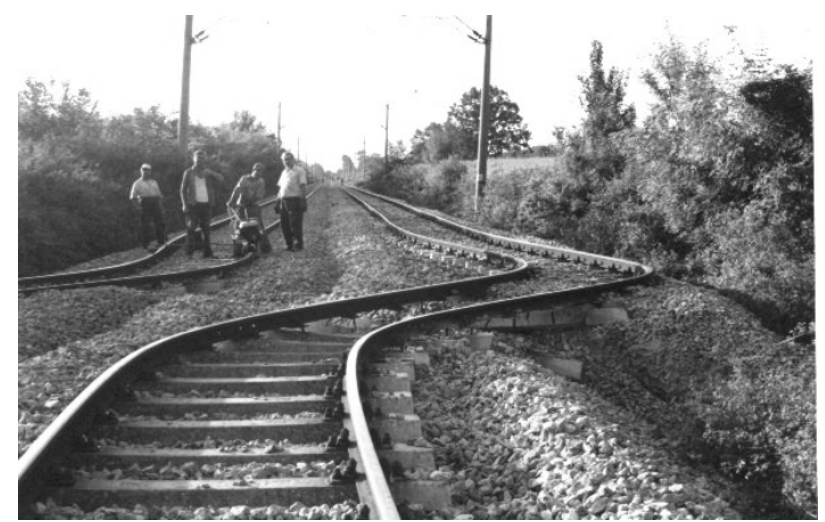

Fig. 7. Istanbul-Ankara Railway (photo by A. Barka).

the very near future.

Acknowledgments. This paper is dedicated to the people died in the earthquakes, Kocaeli and Duzce. The authors would like to thank A. Barka for his valuable figures and photos.

\section{References}

Barka, A., Neotectonics of Marmara region, in Active Tectonics of NWAnatolia-The Marmara Poly Project, edited by Schinler and Pfister, pp. 55-89, VDF, ETH Zurich, 1997.

Barka, A., The August 17 and November 121999 Earthquakes in the Eastern Marmara Sea Region, Proceedings of the International Symposium on the Kocaeli Earthquake, 383-388, Istanbul, December 2-5, 1999a.

Barka, A., Duzce earthquake, TUBITAK Newsletter (Bilim Teknik Dergisi), 40-44, 1999b (in Turkish).

Barka, A. and S. Nalbant, Modelling of the Marmara Earthquakes after year of 1700, Proceedings of the 1st meeting of Active Tectonic Research Group (ATAG-1), Istanbul Technical University press, 32-40, 1998 (in Turkish, with English abstract).

Ferrari, A. H., A. Barkai, E. Jacques, S. S. Nalbant, B. Meyer, R. Armijo, P. Tapponier, and G. C. P. King, Seismic hazard in the Marmara Sea Region following the 17 August 1999 Izmit Earthquake, Nature, 104, 269-273, 2000 .

Kocyigit, A., Segmentation, Kinematics and Seismicity of The North Anatolian Fault System (NAFS) in Marmara Sea Region, NATO Advanced Research Workshop, Istanbul, May 14-17, 2000.

Le Pichon, X., T. Taymaz, and A. M. C. Sengor, The Marmara Fault and the future Istanbul earthquake, Proceedings of The International Symposium on the Kocaeli Earthquake, 41-54, Istanbul, December 2-5, 1999.

Okay, A., N. Gorur, E. Demirbag, A. Boztepe, A. Kaslilar, N. Okay, and I. Kuscu, More than one segment in the Marmara Sea, Cumhuriyet Bilim Teknik (Daily Newspaper Edition), No. 653, 14-16, September 25, 1999.

Reilinger, R., N. Toksoz, S. McClusky, and A. Barka, 1999 Izmit, Turkey Earthquake was no surprise, GSA Today, 10(1), 1-6, 2000.

Sengor, A. M. C., personal communication, 1999.

Taymaz, T., Seismotectonics of the Marmara region: source characteristics of 1999 Golcuk-Sapanca-Duzce earthquakes, Proceedings of The International Symposium on the Kocaeli Earthquake, 55-78, Istanbul, December 2-5, 1999.

Tuysuz, O. and S. C. Genc, Geological Factors Controlling the Distribution of Damage during the 17th August and 12th November 1999 Earthquakes, Proceedings of The International Symposium on the Kocaeli Earthquake, 19-22, Istanbul, December 2-5, 1999.

Ural, O., What Went Wrong?, Proceedings of The International Symposium on the Kocaeli Earthquake, 1-8, Istanbul, December 2-5, 1999.

M. Sahin (e-mail: sahin@itu.edu.tr) and E. Tari 